\title{
SHOULD EUTHANASIA BE A SOLUTION TO THE PROBLEM OF "DECENT" DEATH? (ON THE EXAMPLE OF THE CASE LAMBERT AND OTHERS V. FRANCE)
}

\author{
ЧИ МАС БУТИ ЕВТАНАЗІЯ РОЗВ'ЯЗАННЯМ ПРОБЛЕМИ "ГІДНОӤ" \\ CMЕРТІ? (НА ПРИКЛАДІ СПРАВИ LAMBЕRT AND OTHERS V. FRANCE)
}

\author{
ДОЛЖНА ЛИ ЭВТАНАЗИЯ БЫТЬ РЕШЕНИЕМ ПРОБЛЕМЫ \\ "ДОСТОЙНОЙ" СМЕРТИ? (НА ПРИМЕРЕ ДЕЛА LAMВЕRT AND \\ OTHERS V. FRANCE).
}

\section{Ostrovska B. V.}

PhD (Law), Doctorate, Senior Researcher of International and Comparative Law Department of V. M. Koretsky Institute of State and Law, Expert of UNESCO Chair "Human Rights, Peace, Democracy, Tolerance and International Understanding" at National University of "Kyiv-Mohyla Academy". E-mail: ostrowskabogdana@gmail.com

\section{Островська Б. В.}

Кандидат юридичних наук, старший науковий співробітник відділу міжнародного права та порівняльного правознавства Інституту держави і права імені В. М. Корецького НАН України, експерт кафедри ЮНЕСКО 3 міжнародного права та біоетики "Права людини, мир, демократія, толерантність і взаєморозуміння між народами" в Національному університеті "Києво-Могилянська академія". E-mail: ostrowskabogdana@gmail.com

\section{Островская Б. В.}

Кандидат юридических наук, старший научный сотрудник отдела международного права и сравнительного правоведения Института государства и права имени В. М. Корецкого НАН Украины, эксперт кафедры ЮНЕСКО по международному праву и биоэтике "Права человека, мир, демократия, толерантность и взаимопонимание между народами" в Национальном университете "Киево-Могилянская академия". Е-таil: ostrowskabogdana@gmail.com

Abstract. The legal and bioethical problem of legalizing involuntary passive euthanasia as a practice of ending a person's life, which in particular is in a minimal conscious state and with disabilities, on the example of the case Lambert and Others v. France of the European Court of Human Rights, is explored in this article. Due to the differences between the national legislation of the states on the regulation of euthanasia and given the lack of the international consensus on this issue, as well as the unified position of the judges on the legality of its application in the context of protecting the right to life on the basis of Art. 2 and 3 of the Convention for the Protection of Human Rights and Fundamental Freedoms of 1950, the need to ensure adequate medical care and treatment guaranteed by the state in order to maintain/prolong a person's life (first of all, artificial hydration and nutrition, mechanical ventilation, cardiopulmonary resuscitation, blood transfusions, dialysis, etc.), and subsequent rehabilitation, as well as palliative care as an alternative to euthanasia, is emphasized. Mandatory compliance with the principle of prohibition of discrimination against person based on health status is stressed. The consequences of using involuntary passive euthanasia, including the need to bring to legal liability, are analyzed.

Keywords: involuntary passive euthanasia, "decent" death, right to life, European Court of Human Rights, discrimination.

Анотація. У статті досліджується правова та біоетична проблема легалізації недобровільної пасивної евтаназії як практики припинення життя особи, зокрема яка знаходиться у стані мінімальної свідомості та з обмеженими можливостями, на прикладі справи Європейського суду з прав людини Lambert and Others v. France. $У$ зв'язку з 
відмінністю національного законодавства держав щуодо регулювання евтаназії та з огляду на відсутність міжнародного консенсусу у изьому питанні, а також уніфікованої позиціі суддів щцодо правомірності ї̈ застосування в контексті захисту права на життя на основі cm. 2 та 3 Конвенції про захист прав людини $i$ основоположних свобод 1950 ., наголошується на необхідності забезпечення гарантованої державою належної медичної допомоги і лікування для підтримки/подовження життя особи (насамперед, гідратаиіï, живлення, штучної вентиляиії легень, серцево-легеневої реанімації, переливання крові, діалізу тощо) та подальшої реабілітації, а також паліативної допомоги як альтернативи евтаназії. Підкреслюється обов'язковість дотримання принципу заборони дискримінації особи за станом ї̈ здоров'я. Аналізуються наслідки застосування недобровільної пасивної евтаназї̈, зокрема й необхідність притягнення до юридччної відповідальності.

Ключові слова: недобровільна пасивна евтаназія, "гідна" смерть, право на життя, Європейський суд з прав людини, дискримінація.

Аннотация. B статье исследуется правовая и биоэтическая проблема легализации недобровольной пассивной эвтаназии как практики прекращения жизни человека, который в частности находится в состоянии минимального сознания $u$ c ограниченньми возможностями, на примере дела Европейского суда по правам человека Lambert and Others v. France. B связи с различием национального законодательства государств по регулированию эвтаназии и учитывая отсутствие международного консенсуса в этом вопросе, а также унифицированной позиции судьей о правомерности ее применения в контексте защиты права на жизнь на основании ст. 2 и 3 Конвенции о защите прав человека и основных свобод 1950 г., отмечается необходимость обеспечения гарантированной государством надлежащей медицинской помощии и лечения для поддержания/продления жизни человека (прежде всего, гидратации, питания, искусственной вентиляции легких, сердечно-легочной реанимации, переливания крови, диализа и т.д.), и последующей реабилитации, а также паллиативной помощи как альтернативы эвтаназии. Подчеркивается обязательность соблюдения принципа запрета дискриминации личности по состоянию её здоровья. Анализируются последствия применения недобровольной пассивной эвтаназии, включая необходимость привлечения к юридической ответственности.

Ключевые слова: недобровольная пассивная эвтаназия, "достойная" смерть, право на жизнь, Европейский суд по правам человека, дискриминация.

Introduction. A separate international legal problem related to the end of a human life is the legalization of euthanasia, which raises many legal and bioethical issues concerning the acceleration of the process of dying, defining the criteria of death, the inalienability of the human right to life, as well as the possibility of its limitations. It encourages research and discussions among lawyers, physicians, philosophers and representatives of religious communities, since the concept of life is a fundamental interdisciplinary category. Increasingly, in the context of human rights and dignity, there are speculative discussions regarding the concepts of "quality" of life and "decent" death, which cause considerable public resonance.

Euthanasia is often connected with the right to the dignity of a person linked to a decent life and decent death, to the right to privacy (such as non-interference with privacy), and the prohibition of torture. According to this approach a decent life is identified with the quality of life. However, life is the highest intangible benefit for everyone regardless of their qualitative or quantitative characteristics, otherwise the quality of life becomes the highest good than life itself, when death is offered as a way out to get rid of a "worthless life" [Островська, 2017a: 51].

Sometimes the value of life depends on the cost of treatment, and the meaning of life without pain and suffering fits into the concept of "quality" of life. In this context, euthanasia is promoted as an alternative to "decent" human death. Dissemination of such statements discredits lives of people with disabilities, patients with fatal illnesses, etc., which is a manifestation of discrimination against 
these individuals. Moreover, there is a probability of further expansion of the use of euthanasia to sick newborns, mentally ill, lonely disabled and elderly people as well. In this context, it threatens to become a new form of eugenics, the roots of which reach the Nazi race purification program. At the same time, "increase of temporal, age, geographical or any other mortality rate does not diminish the cost of living in such conditions" [Медведєв, 2019: 69].

The purpose of the article is, on the example of the case Lambert and Others v. France of the European Court of Human Rights to draw the attention of the scientific community to the legal and bioethical problem of legalizing of involuntary passive euthanasia as a practice of ending a person's life, which in particular is in a minimal conscious state and with disabilities.

Due to the differences between the national legislation of states on the regulation of euthanasia and lack of the international consensus on this issue, as well as a unified position of the European Court judges on the legality of its application in the context of protecting the right to life on the basis of Art. 2 and 3 of the Convention for the Protection of Human Rights and Fundamental Freedoms of 1950, the need to ensure adequate medical care and treatment guaranteed by the state in order to maintain/prolong a person's life (first of all, artificial hydration and nutrition, mechanical ventilation, cardiopulmonary resuscitation, blood transfusions, dialysis, etc.), and subsequent rehabilitation, as well as palliative care as an alternative to euthanasia, is emphasized. Mandatory compliance with the principle of prohibition of discrimination against person based on health status is stressed.

Research problem setting. Legal science raises the question of a person's "right" to a "decent" death and euthanasia as a means of exercising that right, in particular at the level of the domestic law of states as evidenced by the case-law of the European Court of Human Rights (hereinafter referred to as the European Court) in the context of the Convention for the Protection of Human Rights and Fundamental Freedoms of 1950 (hereinafter referred to as the European Convention), in particular, its Art. 3 (prohibition of torture) and Art. 8 (right to respect for private and family life) [Островська, 2017b: 20-30]. The European Court tried to find the answer on the legality of the use of euthanasia when a person is unable to express his or her own will. In addition, the issue of termination of life usually requires assistance of other people or committing the active actions that, as a consequence, cause the death of a person ("mercy killing"), which blurs the line between the concepts of "letting die" and "force to die". The European Court "accordingly finds that no right to die, whether at the hands of a third person or with the assistance of a public authority, can be derived from Article 2 of the Convention" (see Pretty v. the United Kingdom, para. 40) [3], that establishes the right to life while recognizing the possibility of internal regulation of the issue of euthanasia for states.

Recent literature review. The works of Ukrainian and foreign experts in the field of law, medicine, philosophy, etc., concerning the legal regulation of the end of human's life, are the scientific and theoretical basis of this research. Particularly, M. Medvedieva (the bioethical aspects of human rights in international law), V. Glushkov, V. Kuts (the criminal legal issues of using the euthanasia), J. Trinyova (the legal regulation of human's life deprivation by request in medical law), V. Pashkov (ensuring the right to life in the palliative care system), B. Zupančič, G. Puppinck, R. Clarke (the international practice of using the euthanasia in the case-law of the European Court of Human Rights), V. Medvediev, P. Muzychenko (the problem of euthanasia legalization in the context of medical ethics and the value of human's life in a terminal state), S. Pustovit (philosophical analysis of the problem of death) and others.

Basic research material. A recent example of the European Court's case-law on the use of euthanasia is the high-profile case of Lambert and Others v. France on 5 June 2015, which gained significant international resonance [2]. It concerned an appeal against the decision of the French Council of State (Conseil d'État) on legalizing the doctor's decision to interrupt artificial nutrition and hydration against citizen Vincent Lambert, who was injured in a road-traffic accident in 2008, which left him in a state of altered (or so-called, minimal) consciousness after a traumatic brain injury (leaving the ability to respond to stimuli - to lead the eyes, cry, feel pain, have autonomous breathing, which are distinctive features from the vegetative state). The applicants in the case were 
his parents and relatives, who believed that such actions were contrary to the State's obligations under Art. 2 (right to life) of the European Convention and strongly opposed his euthanasia, despite the fact that he was not able to express such desire.

The essence of the consideration of this case before the European Court was to answer whether the state's permission to terminate or not apply a treatment, that artificially supports life of a person in a state of complete dependence, can be considered as lawful deprivation of life (that is, a de facto recognition of the right to passive euthanasia due to medical evasion from acting or assisting suicide), and whether such permission is compatible with the observance of the positive state obligations under Art. 2 of the European Convention.

In its judgment, the European Court stated that this case did not concern the State's negative obligations (intentional deprivation of life) within the meaning of Art. 2, and its consideration based solely on the positive obligations of the state (protecting the lives of all, who fall under its jurisdiction). In its final part, unanimously acknowledging the admissibility of the applicants' complaint filed under Art. 2, the European Court held that "there would be no violation of Article 2 of the Convention in the event of implementation of the Conseil d'État judgment of 24 June 2014" (para. 182) [2]. At the same time, the European Court emphasized the lack of consensus among Council of Europe member states on the authorization to disconnect the life-support devices of an individual, and therefore in the field of end-of-life "States should be allowed a margin of appreciation in striking a balance between patients' personal autonomy and the protection of their lives" (para. 135) [2]. The European Court also stressed the importance of the problem raised in this case as it deals with "extremely complex medical, legal and ethical matters" (para. 181) [2].

At the same time, Judges Khanlar Hajiyev, Ján Šikuta, Nona Tsotsoria, Vincent A. De Gaetano and Valeriu Gritsko (in a joint partly dissenting opinion), in para. 2 emphasized that "Article 2 protects the right to life but not the right to die (see Pretty v. the United Kingdom, no. 2346/02, §§ 39-40, ECHR 2002-III). Likewise, Article 3 guarantees a positive right not to be subjected to ill-treatment, but not the "right" whatsoever to waive this right and to be, for example, beaten, tortured or starved to death. To put it simply, both Article 2 and Article 3 are "one-way avenues". The right not to be starved to death being the only right that Vincent Lambert himself could have validly claimed under Articles 2 and 3, we fail to see how it is logically possible to find any lack of "convergence of interests" between him and the applicants in the present case, or even entertain the slightest doubt on this point" [10].

Furthermore, this case cannot be compared with the termination of treatment for a person who has clearly expressed his or her desire not to continue treatment due to his or her physical condition and pain, and accordingly has expressed a reluctance to live or, in view of that situation, clearly refused food and water. Then there could be no objections to discontinuation of hydration and feeding, if domestic legislation provides for that, including the right of medical professionals to refuse to participate in this procedure if it is contrary to their religious, ethical beliefs or other objections to conscience (as an act of conscience). In this context, if, in some situations, "the two rights of the Convention... are at odds with one another: the right to life (with the corresponding duty of the State to protect life), on the one hand, Article 2 and the right to personal autonomy, which falls under Article 8, 'respect for human dignity and human freedom' (emphasized in Pretty v. the United Kingdom, para. 65) may prevail. "But that is not Vincent Lambert's situation" (para. 3 ), who, "according to the evidence available, is in a stable vegetative state, with minimal, if any, consciousness. However, he is not dead - it is a failure of function at one level of the brain, but not at all levels. In fact, he can breathe on his own (without the aid of a life-support apparatus) and can digest food (the gastrointestinal tract is intact and functioning), but has difficulty swallowing, moving solid food down into the esophagus. More critically, there is no evidence, convincing or otherwise, that he is suffering from pain (as opposed to the apparent discomfort of being permanently in bed or in a wheelchair)" [10].

At the same time, the decision states: "food and water are two basic life-sustaining necessities, and are intimately linked to human dignity" (para. 4) [8], that was repeatedly emphasized in numerous international documents, particularly in General Comment No. 12 on the 
right to adequate food (Art.11 of the International Covenant on Economic, Social and Cultural Rights), adopted by the United Nations Committee on Economic, Social and Cultural Rights at its twentieth session on 12 May 1999, as well as in General Comment No. 15 on the right to water (Arts. 11 and 12 of the International Covenant on Economic, Social and Cultural Rights), adopted by the United Nations Committee on Economic, Social and Cultural Rights at its twenty-ninth sessions respectively in November 2000.

According to the judges, "By no stretch of the imagination can Vincent Lambert be deemed to be in an "end-of-life" situation. Regrettably, he will be in that situation soon, after feeding and hydration are withdrawn or withheld. People in an even worse plight than Vincent Lambert are not in an imminently terminal condition (provided there is no other concurrent pathology). Their nutrition - regardless of whether it is considered as treatment or as care - is serving a life-sustaining purpose. It therefore remains an ordinary means of sustaining life and should, in principle, be continued" (para. 6) [10]. As a result, the judges expressed their regret for the "frightening" decision for Vincent Lambert, which marked as "a retrograde step in the degree of protection which the Convention and the Court have hitherto afforded to vulnerable people" (para. 1) [10].

After the judgment of the European Court, the case received a new course. On 26 June 2015, Mr Lambert's parents applied to the European Court for review the case due to newly discovered circumstances, but on 6 July the European Court refused to accept it. Then, on 15 July, the doctors decided to turn off the life support equipment, in response to that the parents appealed to the law enforcement agencies with an application for attempted murder of their son and after that on 23 July, the life support system was restored again. Subsequently, there was a long legal battle between the patient's wife - Rachel Lambert for the termination of her husband's treatment and his parents Viviane and Pierre Lambert on the protection of Vincent's life (in the Châlons-en-Champagne Administrative Court and Reims, Supreme Court of France).

On 9 April 2018, another withdrawing of artificial feeding and hydration of the patient began. On 18 April 2018, "The Call of 70 Doctors: It's Obvious that Vincent Lambert is not at the end of life" [11] was published, in which 70 doctors who specialized in the care of person with disabilities (with altered consciousness) condemned euthanasia and asked to transfer Vincent Lambert from the Palliative Care unit to the Specialized unit for people in this condition, and treat him the same way as person with a disability, but not as a dying person whom he was not.

Subsequently, Vincent's family members urgently appealed to the Administrative Court of Chalon-en-Champagne with a request to stop the abolition of life support measures for their son. After the examination, the court rejected their application on 31 January 2019. Then the applicants referred the case to the State Council (Conseil d'État) as the highest administrative court of the French Republic, which on 24 April 2019 also dismissed their appeal and ruled that the medical decision to withdraw Vincent's hydration and nutrition until his death was not illegal.

On the same day, the applicants requested the European Court to take an interim measure aimed at prevention of the suspension of treatment which supported the life of $V$. Lambert, in accordance with Rule 39 of the Rules of Court, requesting the suspension of the State Council's decision from the 24 April 2019, as well as the ban on the exportation of Vincent from France. On 30 April 2019 the European Court decided to dismiss their application [24]. It stressed that the judgment of the Grand Chamber of 5 June 2015 found that it would not be a violation of Art. 2 (right to life) of the European Convention in case of implementation of the decision of the State Council of 24 June 2014, which withdraw nutrition and hydration of Mr Lambert.

Supported by the European Center for Law and Justice (an international non-governmental organization established in 1998 that dedicated to the promotion and protection of human rights in Europe and worldwide, including the European Court and the United Nations, and has held special Consultative Status before the United Nations/ECOSOC since 2007 [1]), Lambert's parents submitted an application to the UN Committee on the Rights of Persons with Disabilities, which on 3 May 2019 adopted the decision on the need of protecting Mr Lambert's life, which contained a petition to the French government to prevent his euthanasia by continuing nutrition and hydration [20]. Based on its previous decision to consider the report submitted by Spain on 19 October 2011 
under Art. 35 of the Convention on the Rights of Persons with Disabilities 2006, UN Committee on the Rights of Persons with Disabilities stated, that "the right to life is absolute and ... decisionmaking as to whether to stop or suspend treatment essential for the maintenance of life is not compatible with this right" (para. 29) [7]. In addition, this Committee is responsible for ensuring the proper application of the Convention. Therefore, France, having recognized the authority of this Committee, should have complied with the provisions of Part 1 Art. 4 of the Optional Protocol to this Convention, which states that: "At any time after the receipt of a communication and before a determination on the merits has been reached, the Committee may transmit to the State Party concerned for its urgent consideration a request that the State Party take such interim measures as may be necessary to avoid possible irreparable damage to the victim or victims of the alleged violation" [14]. Moreover, respect for these measures is a condition for the effectiveness of the right to appeal to the court.

Two days later, on 5 May 2019, the French Minister of Health, in her response to the Committee, declared, that the medical team responsible for this case was entitled to terminate the care, since the decisions of the UN Committee on the Rights of Persons with Disabilities were not legally binding for them. Although the decisions of this Committee are no subject to direct implementation within the framework of the internal legal order of states (their domestic law), the international system of human rights protection requires cooperation from States. UN committees, including Committee on the Rights of Persons with Disabilities, have global competence. Besides, they "specialize in the protection of certain rights, or categories of persons, while the European Court of Human Rights is non specialized, so that the former consider they should determine the international norm in their field. It should therefore be up to the European Court of Human Rights to fall into line with the Committee on the Rights of Persons with Disabilities on the rights of persons with disabilities, and not the other way around" [19].

Besides, the Minister of Health of France refused to recognize V. Lambert's status of a disabled person, who is in a state of altered consciousness after traumatic brain injury, supporting the position of the doctor who, in agreement with the French authorities, decided to terminate supporting treatment for him, stating that the patient is in a vegetative state. Instead, Art. 25 (f) of the Convention on the Rights of Persons with Disabilities envisages that "States Parties shall ... prevent discriminatory denial of health care or health services or food and fluids on the basis of disability" [5], that the European Court did not even take into account. Moreover, the principles of the Universal Declaration of Human Rights of 1948 and subsequent international documents, adopted on its basis, prohibit discrimination against a person on grounds of his or her health or disability.

Currently, nearly 1,700 patients in France "are waiting" for the same fate as V. Lambert (through "compassion" or for budgetary reasons). There is a direct threat that they will no longer be treated as patients under the protection of the law, but as a "dead weight", according to the director of the European Center for Law and Justice Grégor Puppinck [16].

On the example of the case of V. Lambert, the international community became witness of the fragility of the modern concept of the human right to life and respect for human dignity. The awareness of these concepts by society, in particular by national authorities, determines the further fate of millions of people with disabilities around the world, who may not be treated as patients but as persons at terminal stages of their lives and may receive a death sentence instead of proper medical care due to "compassion" for them.

In 1946, during hearings in Nuremberg, doctors who applied euthanasia for the disabled under a special Nazi program started by Adolf Hitler, were convicted, that formed the basis of modern medical ethics. The present case has become real long-term research of the conformity of the French law on patients' rights and the end of life of 22 April 2005 ("la loi Leonetti") [12] with international law, which de facto permits the euthanasia of persons with disabilities. The main idea laid down in this law - there is the need to apply its provisions only in cases when artificial nutrition and hydration at the end of a person's life make his condition worse. However, the application of this law in the case of Lambert was unacceptable, since these means were necessary 
to maintain the vital activity of his body and did not cause him any harm, and on the contrary - their deprivation condemned him to imminent death.

Since the European Court did not qualify whether nutrition and hydration could be stopped, but simply, as always, referred to the "lack of European consensus" on this key issue, it left V. Lambert virtually doomed to death. After the European Court judgment of 30 April 2019, Mr Lambert's parents filed an emergency petition to the Court of Appeal of Paris, which, after hearing their application, decided to renew treatment on 20 May. The same day, another petition to the European Court was filed by members of Vincent Lambert's family with a request under Rule 39 of the Rules of Court "to indicate to the French State the immediate application of the interim measures demanded of France by the UN Committee on the Rights of Persons with Disabilities (UNCRPD) on 3 May 2019" [22]. However, on 20 May 2019 the European Court "observed that on 30 April 2019 it had decided, having regard to the circumstances, to reject the requests for interim measures submitted to it" and pointed out that "the applicants had submitted no new evidence such as to induce it to change its position" [22].

On June 28 the same year the French Supreme Court, as a court of cassation, reversed the Court of Appeal's decision of May 20 and ruled on the possibility to disconnect the life-support devices that supported Mr Lambert. However, this court did not consider the arguments for or against the support of his life, but only found that the lower court had no proper jurisdiction to hear this case.

On July 1, the European Center for Law and Justice helped V. Lambert's mother organize a request for assistance to the UN Human Rights Council at its 41st session. The motive for such an appeal was that "on two occasions, the Committee on the Rights of Persons with Disabilities asked France to not provoke Vincent's death. But the French government refused the measures, and violates in a shameful fashion its obligations under international law" [23].

But the last hope was lost when on 2 July 2019 doctor of University Hospital of Reims Vincent Sanchez announced the beginning of the termination of "treatment" (nutrition and hydration), which after a 9-day agony ultimately ended in the painful death of 42-year-old V. Lambert on 11 July, who had not waited for a decision to recognize his legal right to life. For his part, Reims prosecutor Matthieu Bourrette announced the opening of an investigation for "the causes of the death", which would include toxicological tests to clarify all the circumstances of the death [21].

At present two proceedings started before the death of Vincent are still pending. The first against doctor V. Sanchez (at the Reims Criminal Court) and the second one - against France (at the UN Committee on the Rights of Persons with Disabilities). These proceedings must be completed, since the death of Vincent Lambert there are testimonies of forced euthanasia [17].

In some cases, if a doctor stops treatment, a patient may die. However, if a doctor deprives the patient of water and food, then a patient will certainly die, moreover with a painful death, since it means not "let him die" but "make him die", which is essentially his murder [6]. Generally, in these and similar cases attention should be paid to the detailed investigation of all the circumstances of the case in order to determine the objective and subjective reasons (motives) of such action, as well as to investigate human rights violations of all involved in involuntary euthanasia of a person.

Unfortunately, the European Court did not find sufficient legal grounds to preserve the life of V. Lambert, in contrast to the Parliamentary Assembly of the Council of Europe, which, citing the same article of the European Convention, substantiated the importance of prohibiting the deliberate deprivation of life of terminally ill or dying, insisting that "the right to life, especially with regard to a terminally ill or dying person, is guaranteed by the member states, in accordance with Article 2 of the European Convention on Human Rights which states that "no one shall be deprived of his life intentionally" (para. 9.3.1.) [18]. Even "a terminally ill or dying person's wish to die never constitutes any legal claim to die at the hand of another person", as well as it "cannot of itself constitute a legal justification to carry out actions intended to bring about death" (para. 9.3.2.9.3.3.). 
In general, the question of the possibility of legalizing euthanasia of persons with disabilities indicates the level of morality in society and tendency of returning to a new level of eugenics, that begins with the selection and reduction (destruction) of embryos, which may have certain developmental disabilities, including their genetic characteristics.

Conclusion. At the UN level, the importance of caring for the preservation of each individual's life, regardless of their health status, and especially - persons with disabilities or temporary health disorders, was recognized. Since the European Court did not qualify whether nutrition and hydration could be considered as treatment that could be stopped, but simply, as always, referred to the "lack of European consensus" on this key issue, it left V. Lambert virtually doomed to death.

According to Boštjan Zupančič, the longest-serving judge at the European Court (from 1998 to 2016), judge of the Constitutional Court of Slovenia and vice president of the United Nations Committee Against Torture, "in the French case Lambert and others v. France (2015) the Court gave an unconvincing verdict, holding that $\mathrm{Mr}$ Lambert had no right to life, even though it acknowledged his legal subjectivity considering this case from the perspective of the right to life (Article 2 of the Convention)" [15]. Although the European Court has to respect a certain "margin of appreciation of States" as a restriction of its action to interfere with the internal affairs of States, "however, over the years, the Court has gradually reduced its self-restraint, stating in hundreds of judgments that the European Convention is a 'living instrument' which should not be taken literally, but the meaning of which should be interpreted "in the light of current conditions", thus allowing its scope to be extended" [15].

"In 2010, to mark its 50th anniversary, the Court accepted the title of The Conscience of Europe when publishing a book with that very title. Assuming, for the sake of argument, that an institution, as opposed to the individuals who make up that institution, can have a conscience, such a conscience must not only be well informed but must also be underpinned by high moral or ethical values. These values should always be the guiding light, irrespective of all the legal chaff that may be tossed about in the course of analyzing a case. It is not sufficient to acknowledge, as is done in paragraph 181 of the present judgment, that a case 'concerns extremely complex medical, legal and ethical matters'; it is of the very essence of a conscience, based on recta ratio, that ethical matters should be allowed to shape and guide the legal reasoning to its proper final destination. That is what conscience is all about. We regret that the Court has, with this judgment, forfeited the abovementioned title" [10], as it is stated in paragraph 11 of the joint partly dissenting opinion in this case.

In agreement with the above comments and emphasizing the true essence of "conscience", European Center for Law and Justice in 2017 published the book "Conscience of Europe?", that contained, according to the opinion of authoritative former judge of the European Court Javier Borrego Borrego, "useful keys for unlocking the important, but complex, jurisprudence of Europe's highest human rights court" [13], which deals with the sometimes unpredictable jurisprudence of the European Court in the controversial spheres of marriage, family life, the sanctity of human life (especially, abortion, euthanasia, artificial reproduction and surrogacy).

The choice of each of the judges, as well as each person, deciding in favor of someone's life or death, directly depends on the ideas about the dignity of a person and the value of one's life. This choice usually depends on the superiority of the materialistic or humanistic qualities in the person, one's religious affiliation, which influences the formation of such ideas. In an objective sense, the value of life does not depend on its biological or functional characteristics, nor on the level of consciousness. Such universal concept of dignity for every person, laid down in the basis of the Universal Declaration of Human Rights of 1948 and subsequent international documents based on its provisions, proclaims the dignity inherent in every person and prohibits discrimination on the grounds of disability or health. Therefore, dignity as an inherent property belongs to each person just because he or she is a person and is not afforded by a decision of the judges. The same applies to "the right to life", which is the only right described by the International Covenant on Civil and Political Rights 1966 as "the inherent right" of every human being (Article 6) [9]. 
As V. Medvedev rightly points out, "...maximally rationalizing, legally defining and narrowing the existence of ethically controversial phenomena, there should be left small, precedent surrounding of individual variations of decisions ... that are formed ad hoc within pre-trial or even judicial proceedings" [Медведєв, 2019: 68], in particular, "by introducing a rule on adherence to their adoption formed ad hoc the circle of relatives and persons, who reflect both public and ideologically significant arguments" [Медведєв, 2019: 69].

Therefore, it is the duty of the state to create conditions for alleviating the sufferings of people, but not stopping them with a "decent" death. In particular, the realization of the human right to palliative care is an important bioethical component of the right to life. In general, the use of euthanasia is an international problem that concerns human rights and encourages the search for interdisciplinary ways of solution through the prism of bioethics, which has become a bridge for combining the natural sciences and humanities (including biology, medicine, law and philosophy), as well as an important area of state cooperation that promotes dialogue between science, cultural and spiritual values [Островська, 2019: 125].

\section{References}

1. About the ECLJ (n.d.) <https://eclj.org/about-us>

2. Case of Lambert and others v. France (2015) 5 June 2015, Appl. No. 46043/14. <http://hudoc.echr.coe.int/eng?i=001-155352>

3. Case of Pretty v. the United Kingdom (2002) 29 April 2002, Appl. No. 2346/02. <http://hudoc.echr.coe.int/eng?i=001-60448>

4. $\quad$ Clarke R. (2017) The "Conscience of Europe?": Navigating Shifting Tides at the European Court of Human Rights. Kindle Edition. <https://adfinternational.org/resource/the-conscience-ofeurope/>

5. $\quad$ Convention on the Rights of Persons with Disabilities and its Optional Protocol (2006) adopted by the General Assembly resolution A/RES/61/106 on 13 December 2006, opened for signature on 30 March 2007. <https://www.un.org/development/desa/disabilities/convention-onthe-rights-of-persons-with-disabilities.html>

6. Dr. John and Barbara Willke (2003) Why Can't We Love Them Both? Questions and Answers About Abortion. Hayes Publishing Co. 2nd edition.

7. Examen des rapports soumis par les États parties conformément à l'article 35 de la Convention (2011) Observations finales du Comité des droits des personnes handicapées. Espagne. CRPD/C/ESP/CO/1. 19 Octobre 2011.

8. General Comment No. 12 The right to adequate food (Art.11 of the International Covenant on Economic, Social and Cultural Rights) (1999) adopted by the United Nations Committee on Economic, Social and Cultural Rights at its twentieth session on 12 May 1999. <https://www.escrnet.org/resources/general-comment-12>

9. International Covenant on Civil and Political Rights (1966) adopted by General Assembly resolution 2200A (XXI) of 16 December 1966, entry into force 23 March 1976. <https://treaties.un.org/doc/publication/unts/volume\%20999/volume-999-i-14668-english.pdf>

10. Joint partly dissenting opinion of judges Hajiyev, Šikuta, Tsotsoria, De Gaetano and Gritco (2015) <https://hudoc.echr.coe.int/eng\#\{\%22itemid\%22:[\%22001-155352\%22]\}>

11. L'appel de 70 médecins: "Il est manifeste que Vincent Lambert n'est pas en fin de vie» (2018) Figaro. 18 avril 2018. <http://www.lefigaro.fr/vox/societe/2018/04/18/3100320180418ARTFIG00261-1-appel-de-70-medecins-il-est-manifeste-que-vincent-lambert-n-est-pasen-fin-de-vie.php>

12. Loi № 2005-370 du 22 avril 2005 relative aux droits des malades et à la fin de vie (2005) $<$ https://www.legifrance.gouv.fr/affichTexte.do?cidTexte=JORFTEXT000000446240\&categorieLi en $=\mathrm{id}>$ 
13. Myjer E. The Conscience of Europe: 50 Years of the European Court of Human Rights (2010) Strasbourg: Council of Europe; London: Third Millennium Publishing, 2010. <https://www.echr.coe.int/Documents/Anni_Book_content_ENG.pdf>

14. Optional Protocol to the Convention on the Rights of Persons with Disabilities (2006) adopted on 13 December 2006, entered into force on 3 May 2008. [ $<$ https://www.un.org/development/desa/disabilities/convention-on-the-rights-of-persons-withdisabilities/optional-protocol-to-the-convention-on-the-rights-of-persons-with-disabilities.html>

15. Puppinck G. (n.d.) About the ECHR: full interview with Boštjan M. Zupančič. <https://eclj.org/geopolitics/echr/about-the-echr--interview-with-bostjan-m-zupancic?lng=en>

16. Puppinck G. (2019) Affaire Vincent Lambert: après la décision de l'ONU, l'État français au pied du mur, Valeurs actuelles. 7 mai 2019. <https://www.valeursactuelles.com/societe/affairevincent-lambert-apres-la-decision-de-lonu-letat-francais-au-pied-du-mur-106697>

17. Puppinck G. (2019) Par-delà la mort, l'affaire Vincent Lambert continue, Valeurs actuelles. Jeudi, 8 Decembre $2019<$ https://www.valeursactuelles.com/clubvaleurs/politique/par-dela-lamort-laffaire-vincent-lambert-continue-113606>

18. Recommendation 1418 (1999) Protection of the human rights and dignity of the terminally ill and the dying (1999) adopted by the Assembly on 25 June 1999 (24th Sitting). <http://assembly.coe.int/nw/xml/XRef/Xref-XML2HTML-en.asp?fileid=16722\&lang=en>

19. The U.N. demands France not to euthanize Vincent Lambert (n.d.) <https://eclj.org/euthanasia/un/lonu-demande-a-la-france-de-ne-pas--debrancher--vincnet-lambert> 20. Vincent Lambert: his mother's moving testimony at the UN in Geneva (n.d.) <https://eclj.org/euthanasia/un/vincent-lambert-his-mother-moving-testimony-at-the-un-in-geneva > 21. Vincent Lambert: ouverture d'une enquête en recherche des causes de la mort (n.d.) $<$ https://www.valeursactuelles.com/societe/vincent-lambert-ouverture-dune-enquete-en-recherchedes-causes-de-la-mort-108824>

22. Vincent Lambert: request for interim measures rejected (2019) Press Release issued by the Registrar of the Court. European Court of Human Rights. ECHR 180 (2019).

23. Viviane Lambert: At the Human Rights Council for her son Vincent (n.d.) $<$ https://eclj.org/euthanasia/un/viviane-lambert--au-conseil-des-droits-de-lhomme-pour-son-filsvincent>

24. Withdrawal of Vincent Lambert's treatment: Court denies request for suspension (2019) Press Release issued by the Registrar of the Court. European Court of Human Rights. ECHR 161 (2019).

25. Медведєв В. (2019) "Людина та ії мозок: чи доречна тотожність на облямівці життя?" [A man and his brain: is identity possible in the edge of life?] Правове регулювання темпоральних меж життя людини: матеріали засідання "круглого столу", м. Київ, 22 жовтня 2019 р., укладач Я.О. Триньова. К., 2019. С. 59-72.

26. Островська Б. В. (2019) ""Якість" життя та "гідна" смерть: біоетична проблема застосування евтаназії в контексті права, медицини, філософії та релігії" ["Quality" of life and " decent " death: bioethical problem of application of euthanasia in the context of law, medicine, philosophy and religion], VIII Міждисциплінарні гуманітарні читання: матеріали міжнародної наукової конференції (Київ, 21 листопада 2019 р.). С. 121-125.

27. Островська Б. В. (2017a) "Евтаназія vs права на життя: проблема прав людини" [Euthanasia vs Right to Life: Human Rights Problem], Наукові записки Інституту законодавства Верховної Ради Украӥни. 2017. № 3. С. 47-53.

28. Островська Б. В. (2017b) "Практика Свропейського суду з прав людини щодо захисту права на життя у біоетичних питаннях" [The practice of European court of human rights on protecting the rights to life in bioethical issues], Держава і право. Серія: "Юридичні науки": зб. наук. праць / Ін-т держави і права ім. В. М. Корецького НАН України. Київ: Вид-во «Юридична думка», 2017. Вип. 75. С. 20-30. 